Humaniora. Czasopismo Internetowe

$\mathrm{Nr} 4(32) / 2020$, ss. 27-41

\author{
MARIANNA MICHAŁOWSKA \\ Adam Mickiewicz University, Poznań, Poland \\ Institite of Cultural Studies, Faculty of Anthropology and Cultural Studies \\ e-mail: mariamne@amu.edu.pl \\ ORCID: 0000-0003-4968-9710
}

\title{
New materialism in art - “new stones” in art@science discourse
}

\begin{abstract}
This study is devoted to three artistic projects based on debris found on the shores of the seas and oceans: plastiglomerates discovered in Hawaii by Kelly Jazvac, recycled waste projects off the coast of river Thames by Inge Sluijs, and plastic waste from the coasts of Norway gathered by Póra Pétursdóttir.

The analyzed works are manifestations of the trend called "new materiality" in art. The artists' goal is to encourage rethinking the status of objects of natural origin that surround us in the context of social relations, especially in the perspective of the nature/ culture dichotomy. Cultural objects of natural origin are the result of human action. Stone and mineral formations are a special example in art practice. They can be studied due to their physical properties, but transformed due to contemporary climate change and pollution they turn into an object proving the cultural transformation of the environment. For this reason, stones found in coastal areas can no longer be considered as raw material for geologists, but as part of human life.

The innovative and creative presentation of objects at exhibitions in the galleries and museums allows the wide audience to understand the relationship between human activities in the environment and its effects on material changes. By focusing on the physical dimension of the matter used, the artists emphasize the role of marine science and comment on socio-political agencies of things, as well as indicate the need for public engagement in activities for marine issues.
\end{abstract}

Keywords: Art@science ${ }_{1}$, Marine observations ${ }_{2}$ Ocean literacy $_{3}$, Anthropocene ${ }_{4}$, Plastiglomerate $_{5}$, Plasma Rock ${ }_{6}$ 


\section{Introduction}

$\mathrm{T}$ he image of the seas and oceans in the social imagination of people living in the Western culture is often shaped by completely different visions presented in the media: it varies from an idyllic image of paradise, shown in popular adventure films, such as The Blue Lagoon and advertised by the tourist industry, to catastrophic messages about tanker crashes, causing ecological disasters (such as the oil spill from MT Exxon Valdez in 1989) or typhoons and tornadoes interfering with human life. ${ }^{1}$ However, in fact, the main theme of such productions is not the oceanic life, ${ }^{2}$ but human struggle with it (as in film Cast Away from 2000 or the ocean classic thriller Jaws from 1975). Is it possible to abandon the Anthropocentric vision of the world and talk about the changes resulting from human activities from the point of view of the nature itself?

In the article I put forward the thesis that artistic realizations, using various types of findings from the sea coast, become effective carriers of marine observations and the changes taking place in seas and oceans (ocean literacy). These may be mineral forms, debris, or fossils resulting from beach pollution. When describing them, artists and scientists use the term "new stones" because - despite the content of artificial substances such as plastic - they take on shapes characteristic for geological objects. ${ }^{3}$

These works, which have a specific artistic status (as a rule, like the avant-garde ready-mades they are not produced by artists, but discovered) are increasingly becoming a tool for an artistic narrative about environmental changes. Therefore, art should be considered as a special means of extracting the sense from contemporary discourses and negotiating social meanings which take into account the contribution of scientific research. ${ }^{4}$

Using scientific methods and referring to the results of scientific research in artistic practice is particularly effective in artistic activities including educational and social elements. Among artists and theoreticians of contemporary art representing the current of "environmental art," we are increasingly confronted with the observation that was noted by C.P. Snow in 1959, i.e. the progressive diversity of languages used by intellectuals and physical scientists ${ }^{5}$ in the field of art is blurred,

${ }^{1}$ I mention the imagination of popular cinema and omit outstanding popular science documentaries - from Jacques Cousteau's excellent education on marine life to Richard Attenborough's film productions.

${ }^{2}$ Perhaps with the exception of Finding Nemo by Pixar Animation Studios (2003).

${ }^{3}$ P.L. Corcoran, Ch.L. Moore, K. Jazvac, An Anthropogenic Marker Horizon in the Future Rock Record, “GSA Today” 2014, no. 24(6), pp. 4-8, doi:10.1130/GSAT-G198A.1.

${ }^{4}$ R.W. Kluszczyński, Trzecia kultura. O współczesnych zwiq̨zkach sztuki, nauk i technologii, Przegląd Kulturoznawczy” 2011, no. 9(1), pp. 24-36.

${ }^{5}$ C.P. Snow, The Two Cultures, "Leonardo” 1990, vol. 23, no. 2-3, pp. 169-173. 
developing a kind of "third culture," within which a new communication between the disciplines of knowledge takes place. In this context, Roger F. Malina writes about "translational studies" that make it possible to understand both their differences and similarities. ${ }^{6}$ Such a "brief encounter" is particularly important for the presentation of the relationships between social behavior and ecological awareness. Researchers from different fields of science and art find here not only a common language, but above all a common goal, i.e. concern for the future of the Earth. The realizations referring to the changes in the natural environment lead to asking vital questions about the nature of human existence as well as about the consequences of human actions occurring in the relationship between nature and culture.

In this article I will analyze three such hybrid artistic and scientific realizations. I call them hybrid because their presentation in art galleries is, on the one hand, a consequence of the cooperation between scientists and artists, and on the other hand, a reflection on the relationship between the human and the non-human. The first example is Plastiglomerates Kelly Jazvac presented at the Human-Free Planet exhibition at Ujazdowski Castle Centre for Contemporary Art in Warsaw, the second - the project of Póra Pétursdóttir and Bjørnar Olsen Unruly Heritage: An Archaeology of the Anthropocene, the third - exhibited during the International Design Week in Milan in 2019 Plasma Rocks produced by Inge Sluijs. These examples were created in collaboration or were inspired by scientific practices of three disciplines of knowledge: geological exploration, archaeology and engineering.

The study outlines the position of these works in the context of two theoretical currents. On the one hand, it asks about the presence of man in the world within the framework of the new materialism, ${ }^{7}$ on the other hand, about the status of objects in the post-humanistic object-oriented ontology. ${ }^{8}$

${ }^{6}$ R.F. Malina, Third Culture? From the Arts to the Sciences and Back Again, "Technoetic Arts: A Journal of Speculative Research” 2012, no. 10(2-3), p. 181, doi:10.1386/tear.10.23.179_1.

${ }^{7}$ M. DeLanda, Assemblage Theory. Speculative Realism, EUP, Edinburgh 2016; G. Deleuze, F. Guattari, A thousand plateaus: capitalism and schizophrenia, transl. and forew. by B. Massumi, The Athlone Press Ltd, London 1988; G. Harman, The Quadruple Object, John Hunt Publishing, Ropley 2011; T. Ingold, Materials against materialism, “Archeological Dialogues” 2007, no. 14(1), pp. 1-16, doi:10.1017/S1380203807002127.

${ }^{8}$ R. Braidotti, Critical Posthuman Knowledges, "South Atlantic Quarterly” 2017, vol. 116, no. 1 (January), pp. 83-96, doi:10.1215/00382876-3749337, A. Cole, The Call of Things: A Critique of Object-Oriented Ontologies, “The Minnesota Review” 2013, 1 May (80), pp. 106-118, doi: 10.1215/00265667-2018414; B. Latour, Politics of Nature, Harvard University Press, Cambridge, Mass, 2004; B. Latour, Agency at the Time of the Anthropocene, "New Literary History” 2014, no. 45(1), pp. 1-18. 


\section{New materialism as a theoretical concept}

The contemporary development of the theory of new materialism can be explained in two ways: firstly, as a response to the "linguistic turn," resulting in poststructural, textualist concepts of the 1970s and 1980s (J. Derrida, J.-F. Lyotard, M. Foucault). Secondly, as the influence of non-anthropocentric philosophy that is developing more and more vividly with the advent of the new millennium. This philosophy sees man as a participant, not a main actor, of reality in the network of relations to non-human agents (B. Latour, G. Harman, M. DeLanda). What inspires such reflections can be found in the discussions around the Actor-Network-Theory of Bruno Latour and Michel Callon, which have been going on since the 1990s, as well as in the growing interest in the agency of culture (J.L. Austin, J. Butler, among others). These concepts emphasize the operative dimension of culture and social relations. Hence the step to include animal studies or plant research (R. Braidotti, D. Haraway) in the humanities, which in turn has led to the introduction of criticism towards Anthropocene and Capitalocene (A. Malm, N. Klein) into the cultural studies.

The proponents of the new materialism refer to the classical realistic philosophy of Plato, Spinoza and Descartes, among others. However, the assemblage theory of Gilles Deleuze and Félix Guattari plays a special role here. The assemblage emphasizes the multiplicity and heterogeneity of relations between substances of different, inconsistent kinds. Manuel DeLanda emphasizes this aspect of the assemblage, which can be compared to "co-functioning," i.e. "a symbiosis, a sympathy." It is therefore a kind of collection of parts that could not work without entering into relationships with each other. It can refer to both ontological and epistemological questions (because, for example, it can be applied to interdisciplinary cooperation).

An alternative to the newly materialistic understanding of physical reality is proposed by the so-called object-oriented ontologies (in the following text I use the abbreviation $\mathrm{OOO}$ ). Also at the heart of $\mathrm{OOO}$ is where a realistic view of interacting objects lies. However, it is emphasized that objects cannot be reduced to relationships. This is more an approach in the spirit of Aristotle, Leibnitz and Husserl. Unlike the traditional Anthropocentric philosophy, the OOO changes the concept of the subject, so far reserved for human individuals. As Bruno Latour writes: "To be a subject is not to act autonomously in front of an objective background, but to share agency with other subjects that have also lost their autonomy." ${ }^{10}$ Within this so-called "flat ontology," all phenomena: organisms, human and animal beings, artistic objects, inanimate substances can be treated as equally participating in the world.

${ }^{9}$ M. DeLanda, Assemblage Theory, p. 1.

${ }^{10}$ B. Latour, Agency at the Time of the Anthropocene, p. 5. 
Both theoretical approaches described here have encountered criticism. On the one hand, they are accused of excessive intellectualism, which still pays insufficient attention to the materiality of objects. ${ }^{11}$ On the other hand, objects are still being anthropomorphized and required to be typically human logocentric, which makes objects "speak" and note their presence. ${ }^{12}$ Therefore, Tim Ingold encourages the abandonment of merely mental perception of objects in favor of the involvement "of the skilled practitioner participating in a world of materials." ${ }^{13}$ In his opinion, the perspective of thinking about things should be changed to participation among things.

Thus, the speculative realism ${ }^{14}$ should include a careful analysis of the objects themselves in their original post-humanistic environmental context. ${ }^{15}$ The introduction of ethical and political threads makes the new materialism an inspiration for social anthropologists (Tim Ingold), archaeologists (Bjørnar Olsen and Christopher Tilley), and “inter-disciplinary humanists” such as Donna Haraway, a biologist and philosopher. Haraway introduces the category of “companion species,” which includes the "significant otherness" of non-human organisms accompanying humans. ${ }^{16}$ Ingold also includes inanimate matter. i.e. stones in this group, which he proposes to explore in their historical complexity.

The artist and writer Deborah J. Haynes sees an opportunity to use the theory of new materialism to oppose the dematerialization of art and proposes a concept of ethical aesthetics. In her opinion, "we need visual art that is responsive to the intersection of the material, ethical, and aesthetic, and informed by an apocalyptic sensibility."17

To sum up, it is worth noting that in this very modified version, the new materialism can inspire artistic activities in four, at least, aspects:

1) the natural and historical sciences operate on material objects, not only philosophically "ponder” about them, thus the newly materialistic approach can:

${ }^{11}$ T. Ingold, Materials against materialism, pp. 2-3.

12 B. Boysen, The embarrassment of being human. A critique of new materialism and object-oriented ontology, “Orbis Litterarum” 2018, no. 73, doi: 10.1111/oli.12174; A. Cole, The Call of Things: A Critique of Object-Oriented Ontologies, “The Minnesota Review” 2013, 1 May (80), pp. 106-118, doi: 10.1215/00265667-2018414.

${ }_{13}$ T. Ingold, Materials against materialism, p. 14.

${ }^{14}$ M. Ferraris, G. Harman, S. De Sanctis, Manifesto of New Realism, SUNY Press., Albany, NY, 2014.

${ }^{15}$ Posthuman Ecologies: Complexity and Process After Deleuze, eds R. Braidotti, S. Bignall, Rowman \& Littlefield Publishers, London 2019; New Materialisms: Ontology, Agency, and Politics, eds D. Coole, S. Frost, Duke University Press, Durham-London 2010.

${ }^{16}$ D. Haraway, Encounters with Companion Species: Entangling Dogs, Baboons, Philosophers, and Biologists, "Configurations" 2006, no. 14(1), pp. 97-114, doi:10.1353/con.0.0002.

17 D.J. Haynes, New Materialism? Or, The Uses of Theory, in: The Art of the Real: Visual Studies and New Materialisms, eds R. Rothman and I. Verstegen, Cambridge Scholars Publishing, Newcastle upon Tyne 2015, p. 9. 
2) constitute the assemblage for scientific research and art, which is best expressed in the activities of art@science current, ${ }^{18}$ not concerned with art and science parallel activity, but rather but with creating a new hybrid form of these two. The replacement of the term "art and science" with a combination of "art(at)science" is therefore significant here. Art does not serve here to illustrate or explain scientific theories, but it can be a mediating tool between a layman-receiver and a qualified scientist. However, experiments conducted in laboratories, in cooperation with researchers, allow the production of artistic objects.

3) OOOs refer to animate and inanimate matter, which is traditionally the subject of natural sciences, examining it in relation to natural processes and human activities. The matter of art starts to consist of unintentionally created objects, which then - by the artist's will - are introduced into the artistic space. ${ }^{19}$

4) pointing to the political, economic and natural causes of the natural changes seems to fit perfectly with the assumptions which are fulfilled by projects broadening social awareness of the role of oceans. Popularization of the ocean literacy can take the form of research and educational projects such as Ocean Literacy for All under the UNESCO agenda, ${ }^{20}$ documentaries on marine life,${ }^{21}$ studies on local awareness of the importance of the oceans for human life, ${ }^{22}$ and, as will be shown later in this text, artistic activities in galleries and museums.

\section{How debris became a work of art}

\subsection{From ready-mades to plastiglomerate}

In 2019 two places in Europe, i.e. Warszawa and Milan ${ }^{23}$ held exhibitions displaying two parts of the same project, which was plastiglomerate samples by Kelly Jazvac.

${ }^{18}$ M. Bakke, Bio-transfiguracje. Sztuka i estetyka posthumanizmu, Wydawnictwo Naukowe UAM, Poznań 2010; R.W. Kluszczyński, Trzecia kultura..., pp. 24-36.

${ }_{19}$ M. Nesbit, Ready-Made Originals: The Duchamp Model, “October” 1986, no. 37, pp. 53-64, doi:10.2307/778518.

${ }^{20}$ F. Santoro, S. Santin, G. Scowcroft, G. Fauville, P. Tuddenham, Ocean literacy for all a toolkit, Paris: IOC/UNESCO \&UNESCO Venice Office 2017 (IOC Manuals and Guides, 80 revised in 2018), https://unesdoc.unesco.org/ark:/48223/pf0000260721 [access: 20.06.2020].

${ }^{21}$ N.H. Mat, Pedagogical Functions of Documentary in Preserving Marine Life, Annual International Conference on Journalism \& Mass Communications, 2007, pp. 20-28, doi: 10.5176/2301-3710_JMComm17.12.

${ }^{22}$ S. Costa, R. Caldeira, Bibliometric Analysis of Ocean Literacy: An Underrated Term in the Scientific Literature, “Marine Policy” 2018, no. 87 (January 1), pp. 149-57, doi:10.1016/j. marpol.2017.10.022; T. Uehara, R. Sakurai, T. Tsuge, Cultivating relational values and sustaining socio-ecological production landscapes through ocean literacy: a study on Satoumi, "Environ. Dev. Sustain.” 2020, no. 22, pp. 1599-1616, doi: 10.1007/s10668-018-0226-8.

${ }^{23}$ Broken Nature: Design Takes on Human Survival, Curated by Paola Antonelli, XXII Biennale di Milano, March $1^{\text {st }}$-September 1 ${ }^{\text {st }}$, 2019; Human-Free Earth, Curated by Jarosław Lubiak, Centre for Contemporary Art Zamek Ujazdowski, Warsaw, March 15 ${ }^{\text {th }}-$ September 22 ${ }^{\text {nd }}$, 2019. 
In glass cases, the artist exhibited small objects, clusters of mineral and artificial substances found in 2013 on Kamilo Beach, Hawaii. The plastiglomerates look like colored stones, bits of colored plastic shine through the minerals, these are fishing ropes, fragments of golf balls - everything that came to the beaches and was processed in the natural cycle under the influence of temperature and sea currents. In simple terms, they can be called stones, although in fact they were formed from beach sediments, lava fragments and living organisms, and most importantly for the new structure of this substance - plastic melted in campfires and spread by the wind and waves. ${ }^{24}$

These objects were found as a result of an exploration carried out by a research team whose members were, apart from Jazvac, a visual artist, a geologist Patricia L. Corcoran and an oceanographer Charles J. Moore.

This realization has two dimensions - the first concerns the status of the findings as a work of art, that is, to put it simply, to answer the question whether an object not created by the author of the realization can be considered a work of art. The second dimension refers to scientific research, proving the character of natural changes.

Let us analyze the first dimension by comparing it with the avant-garde readymades, introduced into art circulation by Marcel Duchamp in $1917^{25}$ and eagerly used later by Dadaists and Surrealists, as well as in the art of the object in neoavant-garde practices.

Firstly, on the one hand, for Duchamp ready-mades were a commentary to consumer culture, to the industrial model of repetition and proved that an artist does not have to create a work of art to be recognized as its creator. ${ }^{26}$ On the other hand, they eluded unambiguous interpretations, provoking symbolic readings of the meanings of an object and its cultural role. ${ }^{27}$ Ready-mades did not allow for unambiguous aesthetic evaluation, undermining the value of art as beauty. In industrial objects, such as: urinals, bottle dryers or bicycle wheels, it is not beauty that is the most important, but function. However, Duchamp took them to the pedestal of art with an artistic gesture.

The issue of plastiglomerate as an art object is both similar and different. They are also created as a result of industrial production, but as its waste, not an object. Unlike ready-mades, there is nothing boring or repetitive about plastiglomerates. Each is different and fascinating like a piece of jewelry. "I find them beautiful and horrific at the same time”28 - Jazvac observed at one of the exhibitions. This beauty

${ }^{24}$ P.L. Corcoran, Ch.L. Moore, K. Jazvac, An Anthropogenic Marker Horizon..., p. 4.

${ }^{25}$ The best known object - The Fountain, that is a mass-produced urinal, signed as R. Mutt, was shown by Duchamp at the exhibition of the Society of Independent Artists in the Grand Central Palace in New York.

${ }^{26}$ M. Nesbit, Ready-Made Originals..., p. 54.

${ }^{27}$ R.E. Krauss, The originality of the avant-garde and other modernists myths, The MIT Press, Cambridge, Mass, London 1987.

${ }^{28}$ The artist's statement, https://www.dezeen.com/2019/04/21/kelly-jazvac-plastiglomerate-milan-triennale/ [access: 20.07.2020]. 
is not the result of human design, although it is undoubtedly the result of global human activity. Secondly, as I observed earlier, ready-mades were manufactured industrially, they had had their function, which they lost when they became an object in the exhibition. Jazvac's samples serve no purpose, they are garbage, even though they were made from fragments of industrial products. However, they lost both function and form. Since they are created as a result of biological mineralization processes, they become closer to the natural world than to industry. Thirdly, artists considered ready-mades a work of art specific to the industrial modern era - its symbol, whereas plastiglomerates are not merely a symbol, but also a scientific proof - a finding confirming the thesis of the existence of the "human geological era," i.e. the Anthropocene.

In this way, these interesting "new stones" bridge the gap between the discourse of art and science. Also in the scientific dimension it is possible to analyze plastiglomerates in several aspects.

First, Jazcac, Corcoran and Moore project fits perfectly into the rapidly developing and natural, social and culturally necessary research on the spread of plastics in different geographical areas, ${ }^{29}$ and on the increasingly expanding "plastisphere." ${ }^{30}$ Secondly, the research team was initially looking for plastic waste, which is a threat to marine organisms. However, they found plastic fragments transformed into new mineral forms. Nevertheless, as Patricia Corcoran emphasizes, natural processes alone are not enough to create such forms. It is necessary to melt them at high temperature, during which impurities such as carbon monoxide, polycyclic aromatic hydrocarbons, and dioxins are released ${ }^{31}$ It is therefore also the effect of "production" of objects. Thirdly, finding plastiglomates, forms that did not exist before the industrial age may prove the thesis about the Anthropocene era correct, and if we would like to take into account the industrial character of waste, also the one regarding the Capitalocene.

\subsection{Archeology of the Anthropocene}

Unruly Heritage: An Archaeology of the Anthropocene is a complex artistic and research project proposed by Dóra Pétursdóttir and Bjørnar Olsen. It combines filed studies and their photographic records with presentation of objects found on the coast of north Norway (in Eidsbukta) and Iceland in galleries and museums. ${ }^{32}$

${ }^{29}$ F. Faure, C. Saini, G. Potter, F. Galgani, L.F. de Alencastro, P. Hagmann, An Evaluation of Surface Micro- and Mesoplastic Pollution in Pelagic Ecosystems of the Western Mediterranean Sea, "Environmental Science and Pollution Research" 2015, no. 22(16), pp. 12190-12197, doi: 10.1007/s11356-015-4453-3.

${ }^{30}$ M. Eriksen, The Plastisphere - The Making of a Plasticized World, "Tulane Environmental Law Journal” 2014, no. 27(2), pp. 153-163.

${ }^{31}$ P.L. Corcoran, Ch. L. Moore, K. Jazvac, An Anthropogenic Marker Horizon..., p. 6.

32 "Arv" Unruly Heritage. Archeology of Anthropocene, curated by Póra Pétursdóttir and Bjørnar Olsen. Tromsø Museum, March $22^{\text {nd }}-$ October 2 ${ }^{\text {nd }}, 2018$, Humboldt University, Berlin. 
In the exhibition halls of Tromsø and Berlin the findings are presented in a similar way. Between the panels with landscape photographs there are tables with objects that we would commonly call garbage: fragments of fishing equipment, everyday objects, thematically sorted cosmetic utensils and toys. However, all these objects have a trace of the past - they are processed by the impact of sea water, polished by currents that brought them to the coasts of the north from other parts of the globe. All this constitutes the legacy of the past in which we live today, ${ }^{33}$ a legacy unwanted, created incidentally, as a result of industrial changes, which is reflected in the original project title, the Norwegian word "arv."

As in the case of the previously described Jazvac realization, the work can be read on two levels, namely in the context of museum artistic practices and its scientific content.

The first level is determined by the exhibition narrative: the photographic documentation represents the current of artistic topographic photography with all its most important features: the focus on the theme of man-altered landscape and the apparent lack of involvement of the lens, which in art criticism is referred to as the deadpan style. ${ }^{34}$

The photographs taken "in-situ" by Póra Pétursdóttir show abandoned buildings, ruined interiors, and views of the coast with piles of buoys, nets and ropes thrown out by the sea in the foreground. As Christopher Tilley writes, the basic term used to refer to the landscape today is embodiment. ${ }^{35}$ It is not enough for a viewer to look at the landscape from a distance, he/she wants to participate in it. The visual language of topographic photography makes it possible because, as image anthropologists write, photography makes it possible to transfer the picture. ${ }^{36}$ The objects placed in front of the panels give the impression of three-dimensionality in a diorama-like way. It is a way of presentation often found in archaeological or ethnographic museums, that is, those whose aim is not only to provide an aesthetic narration, but also (or maybe above all) to pass on knowledge.

The second level refers to the methods and purpose behind the Unruly Heritage project. The creators mention the following resources involved in the project realization: test excavations, soil chemical analysis, photography, video recording, mapping, drawing, and descriptive accounts. ${ }^{37}$ All these methods comply with the assumptions that Ingold proposes in his approach to materialism, emphasizing the

${ }^{33}$ B. Olsen, P. Pétursdóttir, Unruly Heritage: Tracing Legacies in the Anthropocene, “Arkæologisk Forum” 2016, no. 35, pp. 38-46.

${ }^{34}$ Ch. Cotton, The Photograph as Contemporary Art, Thames \& Hudson, London 2004; M. Michałowska, Krajobraz krytyczny w polskiej fotografii - geografie peryferii, "Zeszyty Artystyczne” 2020, no. 1(37), pp. 17-32.

${ }^{35}$ Ch. Tilley, Interpreting Landscapes: Geologies, Topographies, Identities; Explorations in Landscape Phenomenology 3, Routledge, Walnut Creek 2010, p. 25.

${ }^{36} \mathrm{H}$. Belting, Antropologia obrazu. Szkice do nauki o obrazie, transl. by M. Bryl, TAiWPN Universitas, Kraków 2007.

${ }^{37}$ B. Olsen, P. Pétursdóttir, Unruly Heritage..., p. 43. 
commitment of the practitioner, entering the world of objects, and DeLanda in assemblage theory, when he emphasizes the concreteness of the studied phenomena and their interdependencies. According to this concept, the objects-assemblages of different characteristics and properties are "unique historical individuals” with "their properties produced by their interacting parts." 38

The research carried out by Pétursdóttir and Olsen directs the viewers’ attention not only to the findings shown in the exhibition, which prove the impact of human activities on the environment, but also to the method chosen by the researchers.

Pétursdóttir points to the four basic characteristics of archaeology that make this science smoothly enter into assemblage relations with geology, oceanography or sociology. However, the researcher indicates the need to create a new branch of it. She writes: “Anthropocene Archaeology is meant to grasp the dramatic environmental consequences of the industrial revolution - our footprints - as these have evolved for the last 250 years, and intensely accelerated for the last half a century." 39 This new branch of archaeology is characterized by four features: first, it has experience in studying the relationship between culture and nature; second, as a discipline established to study the past and to expand the knowledge of the causes of historical change, it "enables us to learn from the past and prepare for the future"40; third, archaeologists, as experts in the interpretation of human creations, are trained to study their relationship with their environment; and fourth, thanks to the aforementioned characteristics, archaeology is also irreplaceable in dating the Anthropocene.

Both the research conducted by Olsen and Pétursdóttir and the exhibitions they prepare have ethical overtones. The confrontation of the audience with tangible findings collected on the coasts of the Arctic, which in the cultural imagination functions as an area "untouched by human presence," allows us to realize the scale of human interference with the environment. Pétursdóttir and Olsen do not show fictional images and metaphorical stories, on the contrary, they show the "reality," the material proof of this unruly heritage, which cannot be denied.

\subsection{Landfills design}

The third example I have chosen illustrates yet another hybrid relationship between artistic and scientific activities. Inge Sluijs produces Tilbury Tiles, made from plasma rock, a material obtained from landfill waste from the area around Tilbury at the mouth of the Thames. For her project, the artist was nominated for the Material Futures Award in Milan Design Week in 2017 and for the New Material Award

38 M. DeLanda, Assemblage Theory, p. 140.

39 D. Pétursdóttir, Climate change? Archaeology and Anthropocene, “Archaeological Dialogues” 2017, no. 2(24), p. 5, doi.org/10.1017/S1380203817000216.

40 Ibidem, p. 7. 
in 2018. Both awards introduce the designs of the future with new materials and innovative techniques.

Tilbury Tiles are produced in shades of grey (their tone depends on the content of individual components) and decorated with an ornament designed by the artist. Sluijs uses fragments of plasma rock in everyday objects, such as dishes or jewelry. She treats it as natural stone and so looks the structure produced from waste material. If we didn't know that it is an effect of environmental engineering, we wouldn't be able to distinguish it from other substances.

The main components of plasma rocks are Silica, Lime, and Alumina, which undergo a high temperature gasification process. From $100 \mathrm{~kg}$ of landfill waste 20 $\mathrm{kg}$ of Plasma Rock can be produced. ${ }^{41}$

The work of Sluijs has been typical for modern design practice since the avant-garde. Creators have always sought innovative solutions for their projects, experimenting with technologies and materials. Thinking about the future is also a feature of modern design. Since the time of probably the most famous school of applied arts and crafts, the Bauhaus, design has been supposed to teach people to think about the development of society in harmony with nature..$^{42}$ Contemporary activities in the field of bio-design put an even stronger emphasis on this ecological and future-oriented aspect of design. The relationship between the artist's creative approach and innovative technologies is essential in it. William Myers emphasizes the role of cross-disciplinary collaboration, which is necessary "to support the ongoing effort to alleviate the negative impacts of the legacies of the Industrial Revolution." ${ }^{43}$ However, unlike in the past, instead of relying on the processing of raw materials of natural origin (primarily minerals and crude oil), Sluijs relies on deposits of the Anthropogenic origin, i.e. raw materials obtained from secondary sources. It is therefore, a process of recovering materials previously lost. Thus plasma rocks are an example of "new stones" created by human activity. Yet, this time, unlike plastiglomerate, the material was created intentionally, to be reused.

The material used by Sluijs is an interesting example of modern bio-design not only in the context of the artistic, scientific and applicative potential of the produced substance, but also because of its ethical, ecological, economic and cultural and social dimension. Tilbury tiles direct the attention of the audience to the problem of processing waste dumps and wastewater, flowing down the rivers to the seas and oceans. Sluijs indicates the possibilities of their reuse in a creatively disigner-like way, asking a provocative question "Can waste be luxury?" 44 and encouraging what

${ }^{41}$ Information on the website of Inge Sluijs, https://www.ingesluijs.nl/work/brine-awptm [access: 20.07.2020].

42 W. Gropius, Scope of Total Architecture, Collier Books, New York 1962.

43 W. Myers, Bio Design Nature Science Creativity, Thames \& Hudson Ltd., London 2014, p. 9.

${ }^{44}$ Information on the website of Inge Sluijs, https://www.ingesluijs.nl/work/brine-awptm [access: 20.07.2020]. 
the word waste means in colloquial language. Sluijs gives synonyms: "unwanted, excess, superfluous, left over, scrap, extra, unused, useless, worthless." Each of them turns out to be inaccurate when it comes to the renewed material. Moreover, the production of tiles proves to be an opportunity to revive the local community because they are produced by a local company.

Again, speaking of plasma rocks, we can consider assemblage in terms of both physical operations on material and assemblage in the sense of new constellations of connections between sciences and arts. DeLanda's assemblage resembles here the meaning that Roger F. Malina's translational studies are supposed to fulfill. They create a background for networked culture, within which the collaboration between artists, research laboratories and also local producers becomes indispensable. ${ }^{45}$

\section{Discussion and conclusions}

The described projects function in various fields of artistic creation: Kelly Jazvac - at art exhibitions, Dóra Péttursdottir - at scientific exhibitions, Inge Sluijs - in the area of artistic design. In each of them, the artist's creative activity, based on scientific research, shows different aspects of Anthropocene effects on maritime areas. It is not without reason that artistic-scientific research so often focuses on beach and coastal areas. They are sensitive places where human activity and nature meet. However, just as there are no more lands unspoiled by human activity, the seas and oceans can no longer illustrate the myth of the space of the last great wilderness. ${ }^{46}$ Water, and especially the coastline, is an area that perfectly illustrates the thesis about the contemporary state of nature-culture, where nature deposits overlap with human ones. They can become part of the ocean literacy, which today refers not only to the life of the seas themselves, but to their dynamic relationship with the local history and culture of the indigenous people. ${ }^{47}$

In conclusion, it is worthwhile to connect the "new stones" used in the artistic projects to three dimensions: history, structure, and their reuse.

1. In the theory of culture, stones functioned in a specific, anthropomorphic way - they were silent witnesses, which a capable interpreter can make "speak" and with the help of which she/he can reconstruct human history or commemorate the past. ${ }^{48}$

45 R.F. Malina, Third Culture?, p. 180.

${ }^{46}$ D. Pétursdóttir, Climate change?, p. 12.

${ }^{47}$ F. Santoro, S. Santin, G. Scowcroft, G. Fauville, P. Tuddenham, Ocean literacy for all a toolkit; T. Uehara, R. Sakurai, T. Tsuge, Cultivating relational values...

${ }^{48}$ This is an example of various forms of monumental commemoration of events and people, as in Günter Demnig's Stolperstein project - placing stone or metal plates with the names of victims of the Nazism (Jews, Roma, the disabled, religious and sexual minorities, as well as members of political parties). See: A. Huyssen, Present Pasts. Urban Palimpsests and the Politics of Memory, Stanford Univ. Press, Stanford, Ca. 2003; C. Schaumann C., Speaking Stones: Material Agency and Interaction in Christian Enzensberger's Geschichte der Natur, in: German 
Whereas in geology and the natural sciences, stones were examined in a different way and used as a basis for dating epochs and reconstructing the Earth's history.

The cultural inclination to anthropomorphize non-human agents in the new materialism is criticized and the approach inspired by geological sciences and disciplines using field research, such as ethnography and archaeology, is proposed instead..$^{49}$ The "new stones" thus become the basis for criticism of the Anthropocene..$^{50}$

2. Physical structure and chemical composition of the new stones contain substances of industrial origin, which confirms the thesis that it is impossible to distinguish between natural processes and cultural activities. On the one hand, plastiglomerates and plasma rocks are in fact a material assemblage of minerals and industrial waste, transforming the natural environment. On the other hand, in the sphere of art, they acquire symbolic meanings which allow constructing metaphorical images of the relationship between human and non-human agents. Thus, they provoke questions about the structure of beings and their dynamic relationships.

3. Artistic activities based on the exploration of beaches, coasts and coastal landfills can not so much reverse the long-term negative impact of human activity on the natural world, but point to new opportunities for the development of products of the Capitalocene era. Thus, the catastrophic image of the end of the world is contrasted with more optimistic prospects of survival.

In the view proposed here, it is important not to fall into the extremes of thinking: neither directed by Anthropocentric nor non-human materialism. The context and importance of contemporary environmental research requires taking into account the impact of human activity on the non-human world. Inanimate matter and "new stones” provide here a particular kind of testimony to these activities.

translated by Katarzyna Turska

\section{Literature}

Bakke M., Bio-transfiguracje. Sztuka i estetyka posthumanizmu, Wydawnictwo Naukowe UAM, Poznań 2010.

Belting H., Antropologia obrazu. Szkice do nauki o obrazie, transl. M. Bryl, TAiWPN Universitas, Kraków 2007.

Boysen B., The embarrassment of being human. A critique of new materialism and object-oriented ontology, “Orbis Litterarum” 2018, no. 73, doi: 10.1111/oli.12174

Braidotti R., Critical Posthuman Knowledges, “South Atlantic Quarterly” 2017, vol. 116, no. 1 (January), doi:10.1215/00382876-3749337.

Ecocriticism in the Anthropocene. Literatures, Cultures, and the Environment, eds C. Schaumann, H.I. Sullivan, Palgrave Macmillan US, 2017, pp. 165-182, doi: 10.1057/978-1-137-54222-9_10.

49 T. Ingold, Materials against materialism, pp. 1-16; Ch. Tilley, Interpreting Landscapes...

${ }^{50}$ D. Pétursdóttir, Climate change?, pp. 22-23. 
Cole A., The Call of Things: A Critique of Object-Oriented Ontologies, "The Minnesota Review” 2013, 1 May (80), doi: 10.1215/00265667-2018414.

Corcoran P.L., Moore Ch.L., Jazvac K., An Anthropogenic Marker Horizon in the Future Rock Record., “GSA Today” 2014, no. 24(6), doi:10.1130/GSAT-G198A.1.

Costa S., Caldeira R., Bibliometric Analysis of Ocean Literacy: An Underrated Term in the Scientific Literature, “Marine Policy” 2018, no. 87 (January 1), doi:10.1016/j. marpol.2017.10.022.

Cotton Ch., The Photograph as Contemporary Art, Thames \& Hudson, London 2004.

DeLanda M., Assemblage Theory. Speculative Realism, EUP, Edinburgh 2016.

Deleuze G., Guattari F., A thousand plateaus: capitalism and schizophrenia, transl. and forew. by B. Massumi, The Athlone Press Ltd., London 1988.

Eriksen M., The Plastisphere - The Making of a Plasticized World, "Tulane Environmental Law Journal” 2014, no. 27(2).

Faure F., Saini C., Potter G., Galgani F., de Alencastro L.F., Hagmann P., An Evaluation of Surface Micro- and Mesoplastic Pollution in Pelagic Ecosystems of the Western Mediterranean Sea, “Environmental Science and Pollution Research” 2015, no. 22(16), doi: 10.1007/s11356-015-4453-3.

Ferraris M., Harman G., De Sanctis S., Manifesto of New Realism, Albany, SUNY Press, NY 2014.

Gropius W., Scope of Total Architecture, Collier Books, New York 1962.

Haraway D., Encounters with Companion Species: Entangling Dogs, Baboons, Philosophers, and Biologists, “Configurations” 2006, no. 14(1), doi:10.1353/con.0.0002.

Harman G., The Quadruple Object, John Hunt Publishing, Ropley 2011.

Haynes D.J., New Materialism? Or, The Uses of Theory, in: The Art of the Real: Visual Studies and New Materialisms, eds R. Rothman and I. Verstegen, Cambridge Scholars Publishing Lady Stephenson Library, Newcastle upon Tyne 2015.

Huyssen A., Present Pasts. Urban Palimpsests and the Politics of Memory, Stanford Univ. Press, Stanford, Ca. 2003.

Ingold T., Materials against materialism, “Archeological Dialogues” 2007, no. 14(1), doi:10. 1017/S1380203807002127.

Kluszczyński R.W., Trzecia kultura. O współczesnych zwiq̨zkach sztuki, nauk i technologii, "Przegląd Kulturoznawczy” 2011, no. 9(1), Wydawnictwo Uniwersytetu Jagiellońskiego.

Krauss R.E., The originality of the avant-garde and other modernists myths, The MIT Press., Cambridge, Mass, London 1987.

Latour B., Politics of Nature, Harvard University Press, Cambridge, Mass., 2004.

Latour B., Agency at the Time of the Anthropocene, "New Literary History” 2014, no. 45(1).

Malina R.F., Third Culture? From the Arts to the Sciences and Back Again, "Technoetic Arts: A Journal of Speculative Research” 2012, 10(2/3), doi:10.1386/tear.10.2-3.179_1.

Mat N.H., Pedagogical Functions of Documentary in Preserving Marine Life, Annual International Conference on Journalism \& Mass Communications, 2017, doi: 10.5176/23013710_JMComm17.12.

Michałowska M., Krajobraz krytyczny w polskiej fotografii-geografie peryferii, "Zeszyty Artystyczne” 2020, no. 1(37).

Myers W., Bio Design Nature Science Creativity, Thames \& Hudson Ltd., London 2014.

Nesbit M., Ready-Made Originals: The Duchamp Model, 1986, “October” 1986, no. 37, doi:10.2307/ 778518. 
New Materialisms: Ontology, Agency, and Politics, eds Coole D., Frost S., Duke University Press, Durham-London 2010.

Olsen B., Archaeology: The Discipline of Things, University of California Press, Berkeley 2012.

Olsen B., Pétursdóttir P., Unruly Heritage: Tracing Legacies in the Anthropocene, “Arkæologisk Forum” 2016, no. 35.

Pétursdóttir P., Climate change? Archaeology and Anthropocene, "Archaeological Dialogues” 2017, no. 2(24), doi.org/10.1017/S1380203817000216.

Posthuman Ecologies: Complexity and Process After Deleuze, eds R. Braidotti, S. Bignall, Rowman \& Littlefield Publishers, London 2019.

Santoro F., Santin S., Scowcroft G., Fauville G., Tuddenham P., Ocean literacy for all a toolkit, Paris: IOC/UNESCO \&UNESCO Venice Office (IOC Manuals and Guides, 80 revised in 2018), 2017, https://unesdoc.unesco.org/ark:/48223/pf0000260721 [access: 20.06.2020].

Schaumann C., Speaking Stones: Material Agency and Interaction in Christian Enzensberger's Geschichte der Natur, in: German Ecocriticism in the Anthropocene. Literatures, Cultures, and the Environment, eds C. Schaumann, and H.I. Sullivan H.I. (Palgrave Macmillan US), 2017, doi: 10.1057/978-1-137-54222-9_10.

Snow C.P., The Two Cultures. Leonardo, Vol. 23, No. 2/3, New Foundations: Classroom Lessons inArt/Science/Technology for the 1990s., 1990.

Tilley Ch., Interpreting Landscapes: Geologies, Topographies, Identities; Explorations in Landscape Phenomenology 3, Routledge, Walnut Creek 2010.

Uehara T., Sakurai R., Tsuge T., Cultivating relational values and sustaining socio-ecological production landscapes through ocean literacy: a study on Satoumi, "Environ. Dev. Sustain.” 2020, no. 22, doi: 10.1007/s10668-018-0226-8.

\section{Acknowledgments}

The author would like to thanks colleagues from the Institute of Cultural Studies for inspiring and critical discussions and dr. Katarzyna Turska for translation and language consultations. 
